\title{
Characteristic Profiles of an Original Drink Sap from Male and Female Deglet Nour Palm (Phoenix dactylifera L.) during Collection Period
}

\author{
Ines Makhlouf-Gafsi, ${ }^{1}$ Abir Mokni-Ghribi, ${ }^{1}$ Hamadi Attia, ${ }^{1}$ \\ Christophe Blecker, ${ }^{2}$ and Souhail Besbes ${ }^{1}$ \\ ${ }^{1}$ Ecole Nationale d'Ingénieurs de Sfax, Université de Sfax, Laboratoire Analyse, Valorisation et Sécurité des Aliments, \\ route de Soukra, 3038 Sfax, Tunisia \\ ${ }^{2}$ Gembloux Agro Bio-Tech, Université de Liège, Unité de Technologie des Industries Agro-Alimentaires, \\ Passage des Déportés 2, 5030 Gembloux, Belgium
}

Correspondence should be addressed to Ines Makhlouf-Gafsi; makhlouf_inesy@yahoo.fr and Souhail Besbes; besbes_souhail@yahoo.fr

Received 5 November 2015; Accepted 17 January 2016

Academic Editor: David Clay

Copyright ( $) 2016$ Ines Makhlouf-Gafsi et al. This is an open access article distributed under the Creative Commons Attribution License, which permits unrestricted use, distribution, and reproduction in any medium, provided the original work is properly cited.

This work aimed to evaluate the nutritional quality of a typical natural drink from male and female Deglet Nour (DN) date palm (Phoenix dactylifera L.) during the collection period. Dry matter, protein, amino acids, and sugar profiles were determined using AFNOR norm, Kjeldahl method, HPLC, and HPAEC-PAD, respectively. The male sap dry matter content was higher than that of the female. It decreased significantly through the tapping period. During the harvest, the male sap protein content decreased but increased significantly in the female sap. Finally, sugar fraction, for both male and female DN sap, was dominated by sucrose, glucose, fructose, and a small amount of myo-inositol. During the collection time, sugar content is affected by the sex especially for myo-inositol content that increased significantly in the female date sap, unlike that of the male one. This may be related to the fact that the male palm is more resistant to physiological stress, inducing myo-inositol formation during tapping.

\section{Introduction}

In the arid and semiarid regions of the world, human life depends basically on date palm crops. Indeed, date palm represents the major product of oasis farming and supports the undercover crops [1] and it constitutes the principal financial and economic resources of oasis by supplying many other products.

Tapping, one of the exploitation methods of the date palm, is an old traditional practice which consists of the delivery of the top of the trunk leaving a few palms serving as a support for the collector and cutting the top of the palm causing the release of sap [2]. The exuded sap from the trunk during the tapping operation can be directly consumed as a fresh drink or used as an alcoholic beverage after natural fermentation [3].
However, this usual practice has always been marked by a potential danger of the abuse of palm trees and the deterioration of the palm groves. In fact, it deprives the palm of most of its (productive) leaves and food reserves. After tapping is completed (up to three or four months), three to four years are needed for the tree to bear a full crop of dates again and five years before tapping from a new [2]. Although the palm may die after the tapping procedure if the daily scarring is carried on too far, analysing the composition of the sap is the suitable solution to respect the harvest time. This way allows us to stop the collection once the sap nutrient elements decline without reaching the critical levels and therefore avoid the damage of the palm.

To the best of our knowledge, no studies have been published on the effect of time of collection throughout the tapping period and the sex of the palm on DN date palm 
sap. Taking into account these reasons, the aim of this work was to study the variation of chemical composition relative to the palm sex and the collection time. The collected data contributed to giving value addition to DN date palm sap.

\section{Material and Methods}

2.1. Samples Collection and Conservation. This study was carried out over a two-year period (2012 and 2013) on six adult Deglet Nour date palms ( 3 males and 3 females belonging to the same piece of land). In 2012, we selected one male and one female date palm from a palm grove which were subjected to the same sunlight conditions, mineral nutrition, and watering. In 2013, we confirmed our study by the analyses of 2 other male palms and 2 other female palms subjected to the same sunlight conditions, mineral nutrition, and watering. The collection period spanned over seven weeks from May 30 to July 18. During this period, the various samples of male and female sap were collected every week (at the 1st, 7th, 14th, 21st, 28th, 35th, and 42nd days of sap collection). Just after the collection, sodium azide $(0.1 \%)$ was added to all the sap samples to protect them from microbial growth.

All analytical determinations were performed in triplicate. Values were expressed as the mean \pm standard deviation $(\bar{x} \pm \mathrm{SD})$.

2.2. Dry Matter. Dry matter content of male and female date palm sap was determined on the basis of weight differences, after drying at $103^{\circ} \mathrm{C}$ until constant weight, as described by the AFNOR association [4].

2.3. Protein Content. Protein content of male and female date palm sap was determined using Kjeldahl method and 6.25 as a protein conversion factor [5]. Data were expressed as a percentage of dry weight.

2.4. Amino Acid Analyses. Amino acids were determined by high performance liquid chromatography (HPLC) according to the OJEC standard method [6]. $10 \mathrm{~mL}$ aliquot of sample of male and female saps was hydrolysed with $6 \mathrm{~N}$ hydrochloric acid in an ampoule containing $0.1 \%$ phenol (for protection of tyrosine) for $24 \mathrm{~h}$ at $110^{\circ} \mathrm{C}$. After acid hydrolysis, $30 \mathrm{~mL}$ of citrate buffer ( $\mathrm{pH}$ 2.2) was added, and the $\mathrm{pH}$ was adjusted between 0.5 and 1 with $7.5 \mathrm{~N} \mathrm{NaOH}$ and $\mathrm{pH} 2.2$ with a $1 \mathrm{~N}$ $\mathrm{NaOH}$. The sample content was diluted to $100 \mathrm{~mL}$ with citrate buffer after adding $1 \mathrm{~mL}$ of a norleucine solution $(50 \mu \mathrm{M}$ as an internal standard). The sample was filtered through $0.2 \mu \mathrm{m}$ nylon filter before being analysed by HPLC. Sulphurcontaining amino acids, cystine and methionine, were determined after a prehydrolysis oxidation with performic acids [6]. The contents of the different recovered amino acids were presented as $\mathrm{g} / 100 \mathrm{~g}$ dry matter basis. The HPLC system (Biochrom) was equipped with an UV-Vis detector with two wavelengths, of $440 \mathrm{~nm}$ and $570 \mathrm{~nm}$, respectively, one for the proline and the other amino acids and a cation exchange column $(200 * 4.6 \mathrm{~mm})$. The amino acid concentrations were calculated from the standard curves.
2.5. Sugar Analyses. Sucrose, glucose, fructose, and myoinositol were analysed with high performance anion exchange chromatography coupled with pulse amperometric (HPAEC-PAD) detection on a Dionex ICS-3000 Chromatographic System operating at $1 \mathrm{~mL} / \mathrm{min}$. The pressure and temperature were $1,000 \mathrm{psi}$ and $80^{\circ} \mathrm{C}$, respectively. External standards of sucrose, glucose, fructose, and myo-inositol were used for quantification [7].

Relying on the previous study of Ben Thabet et al. [8] which indicates that the fat content in $\mathrm{DN}$ date palm sap is very low $(<0.02 \mathrm{~g} / 100 \mathrm{~g}$ dry matter basis) we did not consider the lipid fraction. So, the total energy was calculated according to the following equation: Energy $(\mathrm{kcal})=4 \times(\mathrm{g}$ protein $+\mathrm{g}$ carbohydrate).

2.6. Statistical Analysis. Statistical analyses were carried out using a statistical software program (SPSS for Windows version 11.0). The data were subjected to a variance analysis using the general linear model (Duncan's test) to determine significant differences between the samples $(p<0.05)$ [9].

\section{Results and Discussion}

3.1. Changes in Dry Matter during Collection of Male and Female Date Palm Sap. The variation in dry matter content relating to the sex of the palm and the collection time is illustrated in Figure 1. At the beginning of the sap collection, the dry matter content for male and female sap matches the average levels of several species of palms varying approximately between 10 and $15 \%$ according to the period of sap collection and the palm tree $[2,10]$. In addition, the dry matter content in male sap was higher than that of female (15.895\% and $11.47 \%$, resp.). After the tapping period, the dry matter content decreases significantly in both male and female sap. In fact, the daily tapping procedure not only imposes an exhaustion of nutritious elements of the trunk [11], but also prevents palms from rebuilding their reserves through photosynthesis reaction by depriving them of most of their productive leaves [2].

3.2. Changes in Protein Content during Collection of Male and Female Date Palm Sap. The variation in protein content according to the palm sex and the collection time is illustrated in Figure 2(a). The protein content of the male and female date palm sap, as the case of many species of palm trees, is considered relatively low (below $5.6 \%$ dry matter basis over the period of collection) $[12,13]$. In the first days of collection, the male date palm sap, as well as Borassus flabellifer L. palms sap [14], contains a higher amount of total proteins than that of the female $(4.99 \%$ versus $3.17 \%$ dry matter basis, resp.). The statistical study of the change in protein content during the collection period revealed a decreasing curve for the male during the first weeks of the sap harvest followed by stabilization from the fourth week. However, for the female sap, there is an increasing curve throughout the whole collection period. 


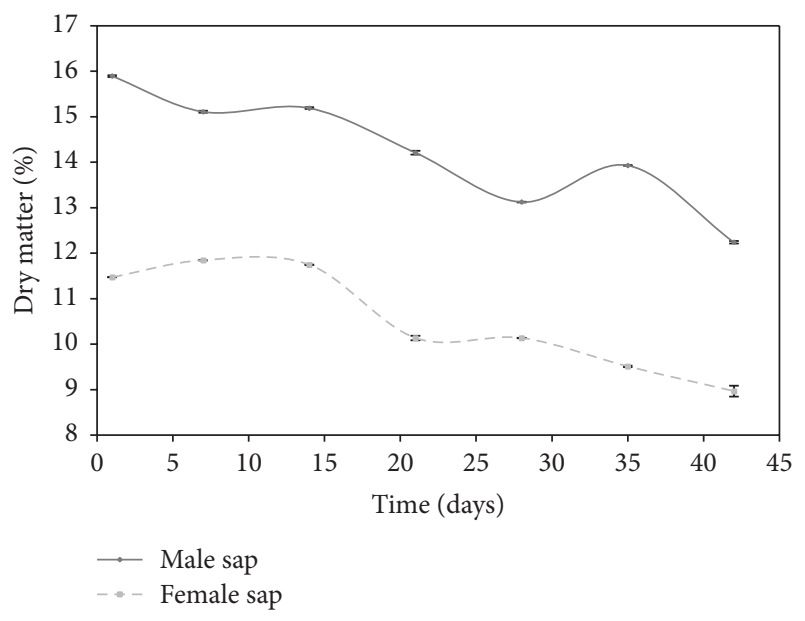

FIGURE 1: Variation of dry matter content of male and female date palm sap according to the collection time.

3.3. Changes in Amino Acid Composition during Collection of Male and Female Date Palm Sap. The variation in amino acid content (dry matter basis) relative to the sex of the palm and the time of collection (Figure 2(b)) has the same shape as that of the protein content (dry matter basis). However, the amino acid content is much lower than the protein content. This proves that the majority of proteins in the sap of the date palm are heteroproteins whose hydrolysis provides not only amino acids but also one or more different molecules (phosphates, carbohydrates, lipids, etc.) [15].

Statistical analysis of Table 1 shows that glutamine and asparagine are the major amino acids in both male and female palm sap like in the case of most plants [16] such as Casuarinaceae [17], Coconut palms [18], and Arenga pinnata palm $[19,20]$.

Classified as nonessential, glutamine is the topic of a great deal of research which suggests that this amino acid is a conditionally essential amino acid in several physiological situations [21]. In fact, it is the most abundant free amino acid in the human body. In addition to its role in proteins formation and amino acid transamination, glutamine has a regulator capacity in immune and cell modulation and its deficiency reduces the proliferation of lymphocytes, influences the expression of surface activation markers on lymphocytes and monocytes, affects the production of cytokines, and stimulates apoptosis [22].

The statistical analysis also revealed that the male sap contains a higher amount of arginine and serine than the female sap throughout the collection period.

Compared to the male sap, the female presents higher essential amino acid content (Table 2). These levels increased significantly from the first week and reached a maximum at the 7th week of sap collection. This is probably due to the daily tapping procedure which results in a decline in the nutritive level. To face this stress, the plant resorts to a supplementary synthesis of the essential amino acids. Collection of Male and Female Date Palm Sap. The high performance liquid chromatography analysis showed that sucrose was the main form of carbon transport in male and female date palm sap throughout the collection period (Figures 3(a) and 3(b)). In addition to sucrose, we also detected small amounts of glucose and fructose (Figures 3(a) and $3(\mathrm{~b})$ ). These results are in accordance with previous works on phloem sap of other plant species such as Deglet Nour palms [8], Coconut palms [18], and the perennial ryegrass plant Lolium perenne L. [19].

The statistical study revealed that the sucrose content of the female sap was higher than that of the male sap during the first five weeks of collection. After that, the sucrose content in the female sap was close to that of the male sap in the sixth week (61.82 and 64.97 dry matter basis in male and female sap, resp.) and the seventh week (45.93 and 44.25 dry matter basis in male and female sap, resp.).

The statistical analysis also showed that the male sap sucrose profile was characterized by a gradual rise in sucrose content from the first week and reached a maximum in the third week before dropping thereafter. A similar sucrose profile was observed in Raphia hookeri palms from Nigeria [11]. However in the female sap, the sucrose content remained higher than $75 \%$ during the first 5 weeks and dropped thereafter until the 7 th week. These results provide data on the maximum amount of sucrose produced by Phoenix dactylifera L. palm according to the time of collection and the sex of the palm.

In both male and female sap, we noticed that when the level of sucrose, the major sugar, decreased, the glucose and fructose contents increased (Figures $3(\mathrm{a})$ and $3(\mathrm{~b})$ ). Based on earlier studies on oil palm sap which proved that sucrose was quantitatively fermented to monosaccharides and organic acids by yeast and various bacteria [23-25], we can advocate that sucrose is the result of photosynthetic activity in the date palm (Phoenix dactylifera L.). Glucose and fructose are metabolic products of sucrose by invertase proteins. These enzymes are involved in glycolysis and related to Saccharomyces cerevisiae which naturally belongs to the microflora of date palm sap [26]. As shown in Figures 3(a) and $3(\mathrm{~b})$, the sex of the palm affects the invertase activity during the collection period. Indeed, this activity is bell-shaped with a minimum in the 14th day in male sap and has an increasing pace throughout the collection period in the female sap.

\subsubsection{Evolution of Myo-Inositol Profile during Collection of} Male and Female Date Palm Sap. The high performance liquid chromatography analysis revealed in addition to sucrose, glucose, and fructose a small amount of myo-inositol in both male and female date palm sap (less than 1.1\% and 2.3\% dry matter basis in male and female sap, resp., throughout the collection period) (Figure 3(c)).

Myo-inositol is an important molecule in the plant biology and has a significant impact on normal plant growth and development [27]. In fact, it is involved in many biological functions such as phosphatidylinositol (PI) signaling pathway, auxin storage and transport, phytic acid biosynthesis, and cell wall biosynthesis. One particularity of myo-inositol is its involvement in the production of stress related molecules [27]. The accumulation of inositol and inositol derivatives in 


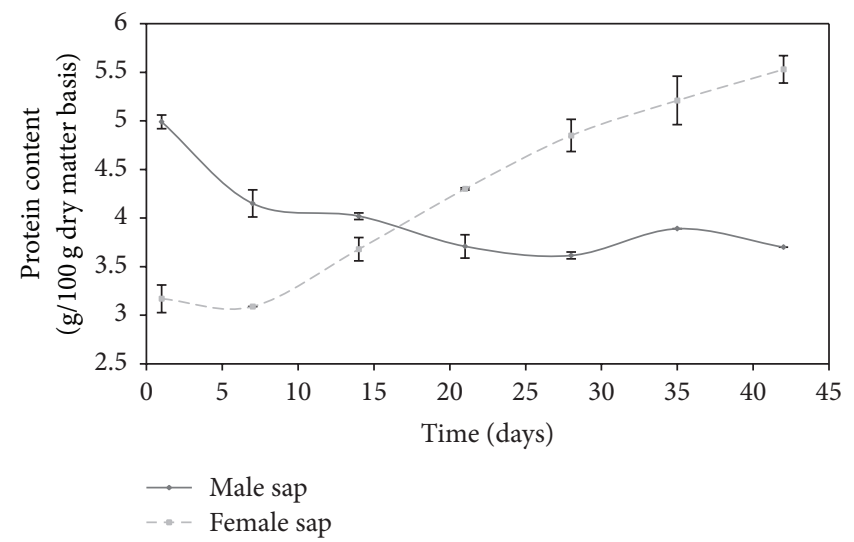

(a)

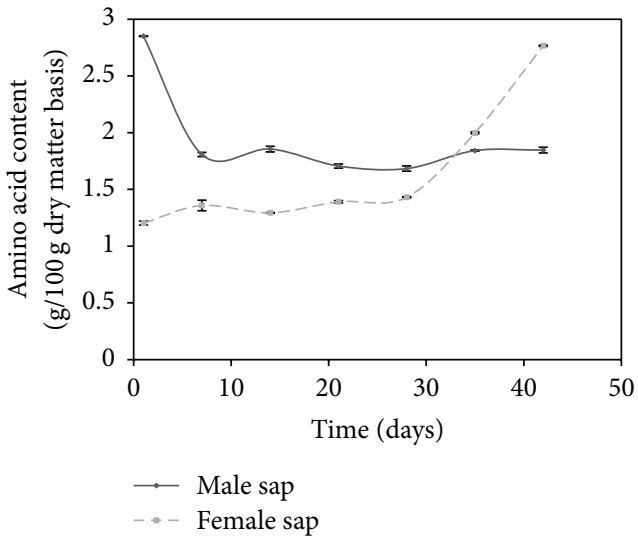

(b)

FIGURE 2: Variation of protein and amino acid contents of male and female date palm sap according to the collection time. (a) Variation of protein content of male and female date palm sap according to the collection time. (b) Variation of amino acid content of male and female date palm sap according to the collection time.

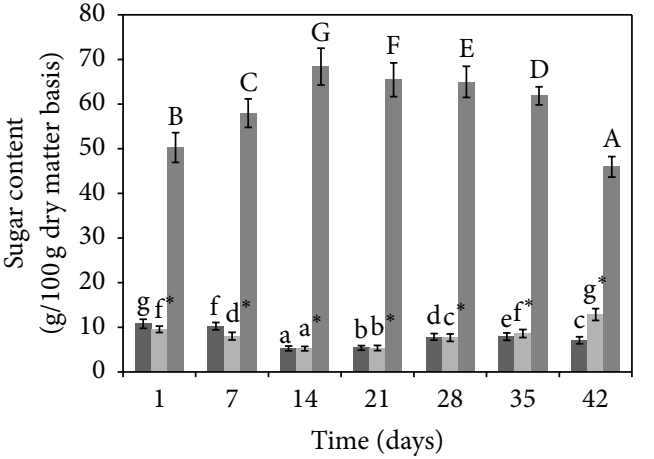

Glucose
Fructose
Sucrose

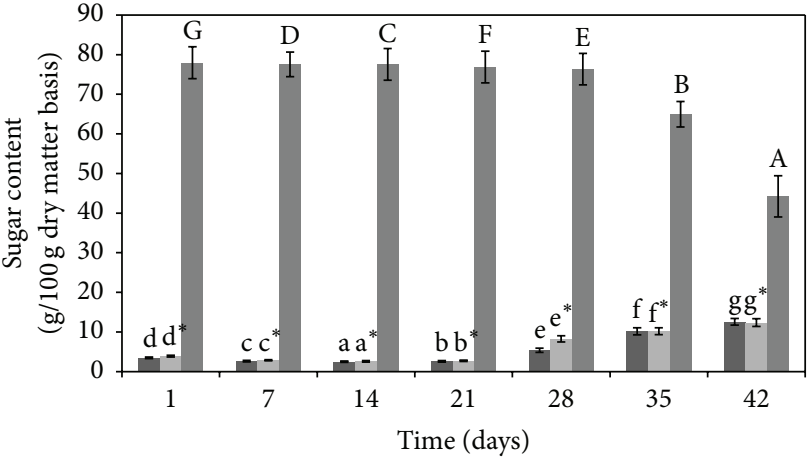

Glucose

Fructose

- Sucrose

(a)

(b)

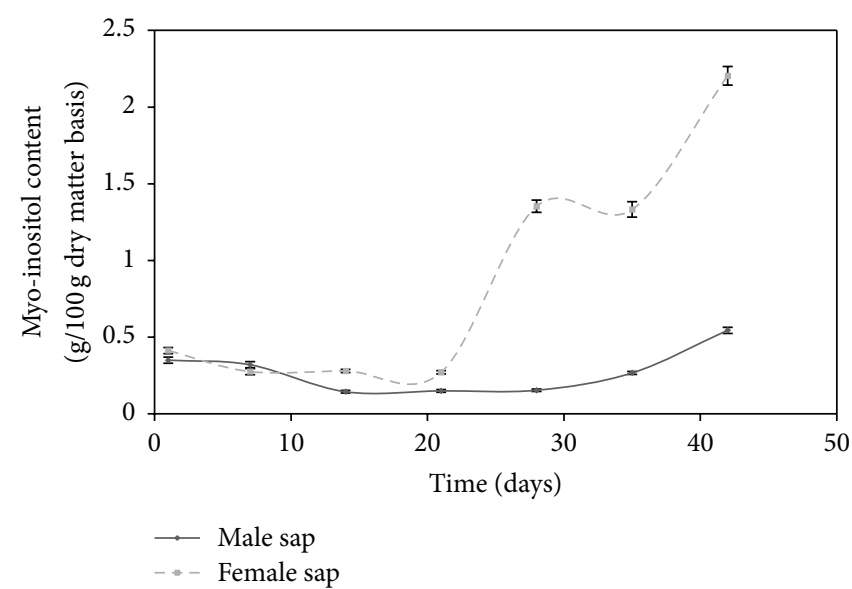

(c)

Figure 3: Variation of sugar contents of male and female date palm sap according to the collection time. (a) Variation of glucose, fructose, and sucrose contents in male date palm sap according to the collection time. (b) Variation of glucose, fructose, and sucrose contents in female date palm sap according to the collection time. (c) Variation of myo-inositol content in male and female date palm sap according to the collection time. (a) Means with different small letters are significantly different $(p<0.05)$. Means with different capital letters are significantly different $(p<0.05)$. (b) Means with different small letters are significantly different $(p<0.05)$. Means with different capital letters are significantly different $(p<0.05)$. 


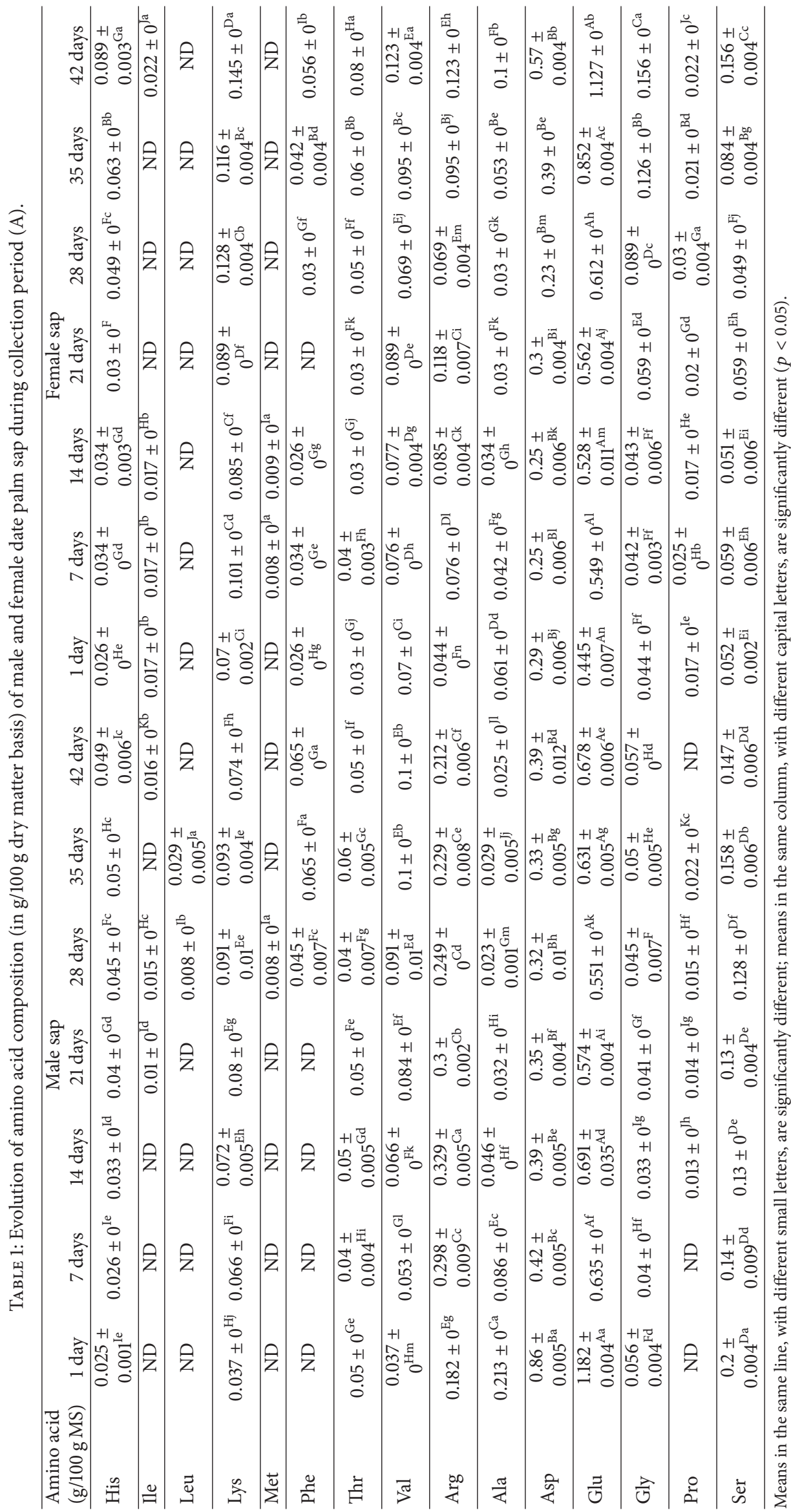




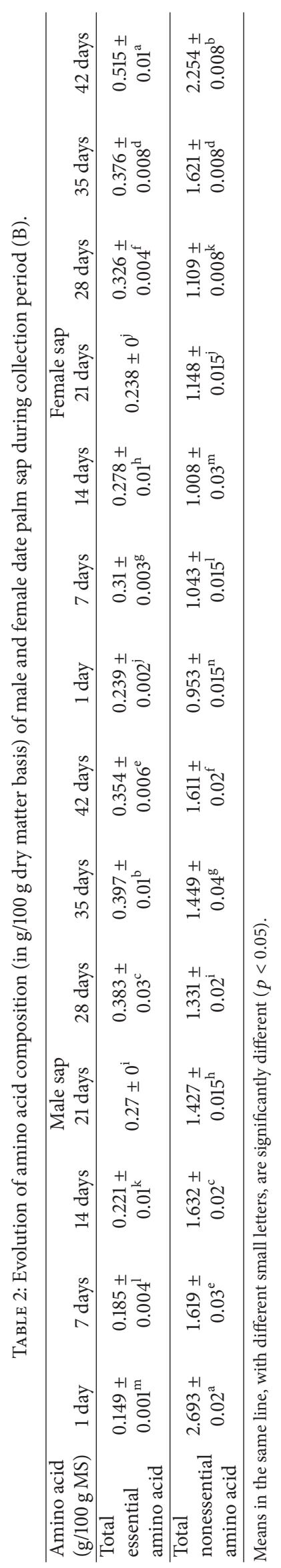


response to salinity has been studied extensively in Mesembryanthemum crystallinum (ice plant) under drought and salt stress. It was found that inositol and its derivatives contribute to the plant protection against salt stress [28].

The daily tapping procedure results in another type of stress infringed on the plant biology at the nutritional level since a lot of nutrients are removed from the trunk [11].

Thus, we can explain the significant increase in myoinositol content in both male and female sap during the last three weeks of collection period (Figure 3(c)) which is characterized by a significant drop in dry matter (Figure 1) and sucrose contents (Figures 3(a) and 3(b)). However, the male sap contains a lower myo-inositol content compared to that of the female during the last three weeks of collection period. This result leads to the deduction that the male palm is more resistant to stress imposed by the traditional practice of tapping than the female palm, taking into consideration that the palms are in the same sunlight conditions, mineral nutrition, and watering.

The biosynthesis of myo-inositol and thereafter stress related molecules involves an enzymatic armature. First, the biosynthetic conversion of D-glucose to myo-inositol involves three enzymatic steps through hexokinase, Ins(3)P1 synthase, and myo-inositol monophosphatase [28]. After that, isomerization enzymes and myo-inositol methylation and other isomeric (scyllo-, chiro-, muco-, and neo-) inositols are involved in the formation of O-methyl inositols (sequoyitol, bornesitol, quebrachitol, pinitol, ononitol, etc.) which participate in stress related responses [28].

3.4. Energy. The energy contribution of the DN palm sap is considered high (greater than $280 \mathrm{kcal}$ per $100 \mathrm{~g}$ of dry weight) for both sexes and throughout the collection period. The energy provided by $100 \mathrm{~g}$ dry matter of palm sap, as shown in Figure 4, was significantly affected by the sex of the tree and the collection period. In fact, the female date palm sap has the highest energetic contribution ranging from 308 to $385 \mathrm{kcal} / 100 \mathrm{~g}$ of dry weight compared to that of the male ( 280 to $336 \mathrm{kcal} / 100 \mathrm{~g}$ dry weight). On the other hand, we noticed that the 5 th week of sap collection was characterized by the highest energetic value for both male $(336 \mathrm{kcal} / 100 \mathrm{~g}$ dry weight) and female ( $385 \mathrm{kcal} / 100 \mathrm{~g}$ dry weight) $\mathrm{DN}$ palm sap.

\section{Conclusion}

This study on the effect of the collection time throughout the tapping period and the sex of the palm on Phoenix dactylifera L. sap constitutes a new issue to investigate a natural product rarely studied. Indeed, the obtained results are rich in information and provide novel data.

First, this study elucidates different nutritional profile for male and female DN palm sap. In fact, the change in protein, amino acid, sucrose and myo-inositol contents, energy contribution, and invertase activity in DN palm sap through the harvest period show differences between male and female palm trees. These analyses were performed on 6 adult palms. The same analyses should be performed on

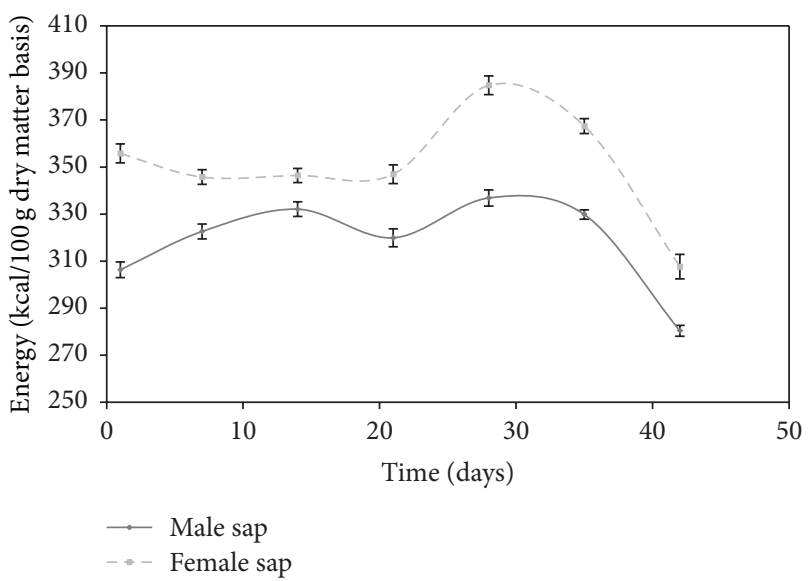

FIGURE 4: Variation of energy contribution of male and female date palm sap according to the collection time.

young palms to study whether their sap composition is the same as that of adults, since the composition of sap in young and adult plants may be different for the nutritional requirements to the reproductive period. However, this study is a further step in the investigation of a possible sexual identification in date palm at an early stage.

Second, this study elucidates the idea of stress infringed by this traditional practice on the palm physiology through the significant increase in myo-inositol, which is involved in the production of stress related molecules, during the last 3 weeks of the collection period in both male and female sap. In addition, this study proves that the male palm is more resistant to stress imposed by the tapping operation than the female palm.

Finally, this study can be considered as a measure to regulate tapping and preserve palm groves from deterioration by limiting the collection period to 4 weeks only. In fact, beyond 4 weeks, the nutrient elements in both male and female sap decline remarkably.

\section{Conflict of Interests}

The authors report no conflict of interests. The authors are alone responsible for the content and writing of the paper.

\section{Acknowledgment}

The authors express their gratitude to the Unite de Technologie des Industries Agro-Alimentaires, Gembloux, Belgium, for their collaboration in this research.

\section{References}

[1] S. Zehdi, H. Sakka, A. Rhouma, A. Ould Mohamed Salem, M. Marrakchi, and M. Trifi, "Analysis of Tunisian date palm germplasm using simple sequence repeat primers," African Journal of Biotechnology, vol. 3, no. 4, pp. 215-219, 2004.

[2] W. H. Barreveld, "Date palm products," FAO Agricultural Services Bulletin 101, FAO, Rome, Italy, 1993. 
[3] I. Makhlouf-gafsi, A. Mokni-ghribi, B. Bchir et al., "Foamability and foam stability of male and female date palm sap (Phoenix dactylifera L.) during the collection period," Food Biophysics, vol. 10, no. 3, pp. 360-367, 2015.

[4] Food and Agriculture Organization of the United Nations, “AFNOR NF V 04-207," in Lait et Produits Laitiers, vol. 1, pp. 137138, Food and Agriculture Organization of the United Nations, Rome, Italy, 1999.

[5] Food and Agriculture Organization of the United Nations, “AFNOR NF V 04-211," in Lait et Produits Laitiers, vol. 1, pp. 195198, Food and Agriculture Organization of the United Nations, Rome, Italy, 1999.

[6] Official Journal of the European Communities (OJEC), "Determination of amino acid in feed by HPLC-development of an optimal hydrolysis and extraction procedure by the EU Commission DGXII in three international collaborative studies," Official Journal of the European Communities, vol. L 257, pp. 1428, 1998.

[7] B. Bchir, S. Besbes, R. Karoui, M. Paquot, H. Attia, and C. Blecker, "Osmotic dehydration kinetics of pomegranate seeds using date juice as an immersion solution base," Food and Bioprocess Technology, vol. 5, no. 3, pp. 999-1009, 2012.

[8] I. Ben Thabet, S. Besbes, H. Attia et al., "Physicochemical characteristics of date sap 'lagmi' from deglet nour palm (Phoenix Dactylifera L.)," International Journal of Food Properties, vol. 12, no. 3, pp. 659-670, 2009.

[9] O. Kilincceker, I. S. Dogan, and E. Kucukoner, "Effect of edible coatings on the quality of frozen fish fillets," LWT-Food Science and Technology, vol. 42, no. 4, pp. 868-873, 2009.

[10] C. Dalibard, "Overall view on the tradition of tapping palm trees and prospects for animal production," Livestock Research for Rural Development, vol. 11, no. 1, pp. 36-77, 1999.

[11] F. I. Obahiagbon and A. U. Osagie, "Sugar and macrominerals composition of sap produced by Raphia hookeri palms," African Journal of Biotechnology, vol. 6, no. 6, pp. 744-750, 2007.

[12] F. I. Obahiagbon, "A review of the origin, morphology, cultivation, economic products, health and physiological implications of Raphia palm," African Journal of Food Science, vol. 3, no. 13, pp. 447-453, 2009.

[13] I. Makhlouf-Gafsi, A. Mokni-Ghribi, B. Bchir, H. Attia, C. Blecker, and S. Besbes, "Physico-chemical properties and amino acid profiles of sap from Tunisian date palm," Scientia Agricola, vol. 73, no. 1, pp. 85-90, 2016.

[14] D. Barh and B. C. Mazumdar, "Comparative nutritive values of palm saps before and after their partial fermentation and effective use of wild date (Phoenix sylvestris Roxb.) sap in treatment of anemia," Research Journal of Medicine and Medical Sciences, vol. 3, no. 2, pp. 173-176, 2008.

[15] J. P. Borel, A. Randoux, F. X. Marquet et al., Biochimie Dynamique, De Boeck and Larcier, Département de Boeck Université, Paris, France, 1997.

[16] W. N. Fischer, B. André, D. Rentsch et al., "Amino acid transport in plants," Trends in Plant Science, vol. 3, no. 5, pp. 188-195, 1998.

[17] K. B. Walsh, B. H. Ng, and G. E. Chandler, "Effects of nitrogen nutrition on xylem sap composition of Casuarinaceae," Plant and Soil, vol. 81, no. 2, pp. 291-293, 1984.

[18] S.-I. Nakamura, A. Watanabe, P. Chongpraditnun et al., "Analysis of phloem exudate collected from fruit-bearing stems of coconut palm: palm trees as a source of molecules circulating in sieve tubes," Soil Science and Plant Nutrition, vol. 50, no. 5, pp. 739-745, 2004.
[19] V. Amiard, A. Morvan-Bertrand, J.-B. Cliquet et al., "Carbohydrate and amino acid composition in phloem sap of Lolium perenne L. before and after defoliation," Canadian Journal of Botany, vol. 82, no. 11, pp. 1594-1601, 2004.

[20] C. W. Ho, W. M. W. Aida, M. Y. Maskat, and H. Osman, "Changes in volatile compounds of palm sap (Arenga pinnata) during the heating process for production of palm sugar," Food Chemistry, vol. 102, no. 4, pp. 1156-1162, 2007.

[21] J. M. Matés, J. A. Segura, J. A. Campos-Sandoval et al., "Glutamine homeostasis and mitochondrial dynamics," The International Journal of Biochemistry \& Cell Biology, vol. 41, no. 10, pp. 2051-2061, 2009.

[22] E. Roth, "Nonnutritive effects of glutamine," The Journal of Nutrition, vol. 138, no. 10, pp. 2025S-2031S, 2008, 7th Amino Acid Assessment Workshop.

[23] S. I. Faparusi, "Effect of $p \mathrm{H}$ on the preservation of palm wine by sulfite," Journal of Applied Microbiology, vol. 18, no. 1, pp. 122123, 1969.

[24] P. I. Eapen, "Palm wine studies," in Proceedings of the 17th Annual Report of the Nigerian Institute for Oil Palm Research, pp. 78-79, Benin, Nigeria, 1970-1971.

[25] W. Van Pee and J. G. Swings, "Chemical and microbiological studies on Congolese palm wines. (Elaeis guineensis)," East African Agricultural and Forestry Journal, vol. 36, no. 3, pp. 331$314,1971$.

[26] I. Ben Thabet, F. Francis, E. De Pauw et al., "Characterisation of proteins from date palm sap (Phoenix dactylifera L.) by a proteomic approach," Food Chemistry, vol. 123, no. 3, pp. 765770, 2010.

[27] J. C. Styer, Regulating inositol biosynthesis in plants: myoinositol phosphate synthase and myo-inositol monophosphatase [Ph.D. thesis], Faculty of Virginia Polytechnic Institute and State University, Blacksburg, Va, USA, 2000.

[28] F. A. Loewus and P. P. N. Murthy, "Myo-inositol metabolism in plants: a review," Plant Sciences, vol. 150, pp. 1-19, 2000. 


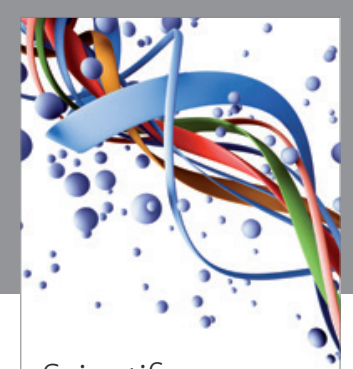

Scientifica
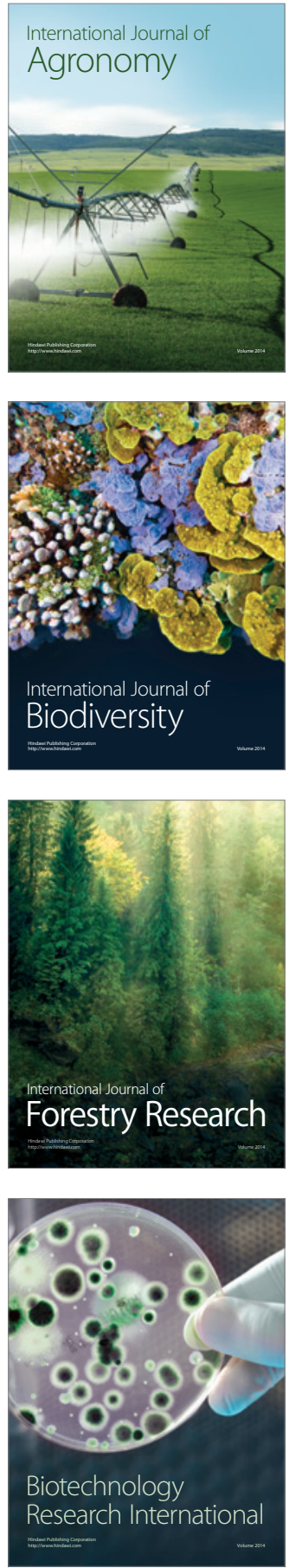
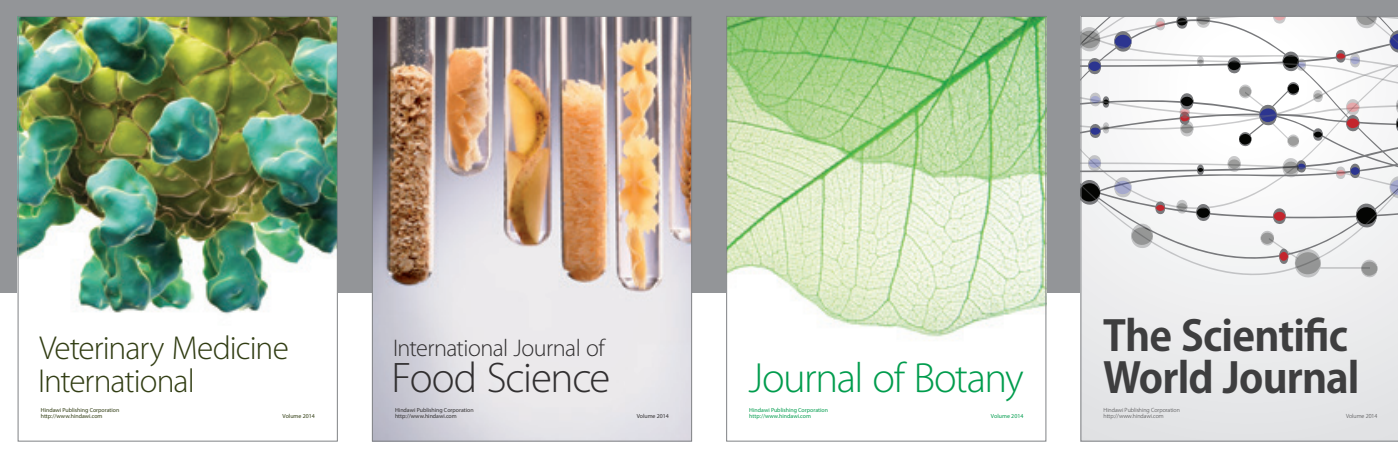

The Scientific

\section{World Journal}

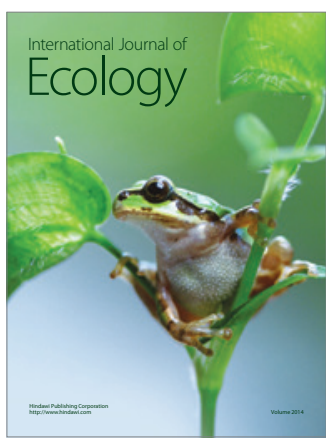

\section{Hindawi}

Submit your manuscripts at

http://www.hindawi.com
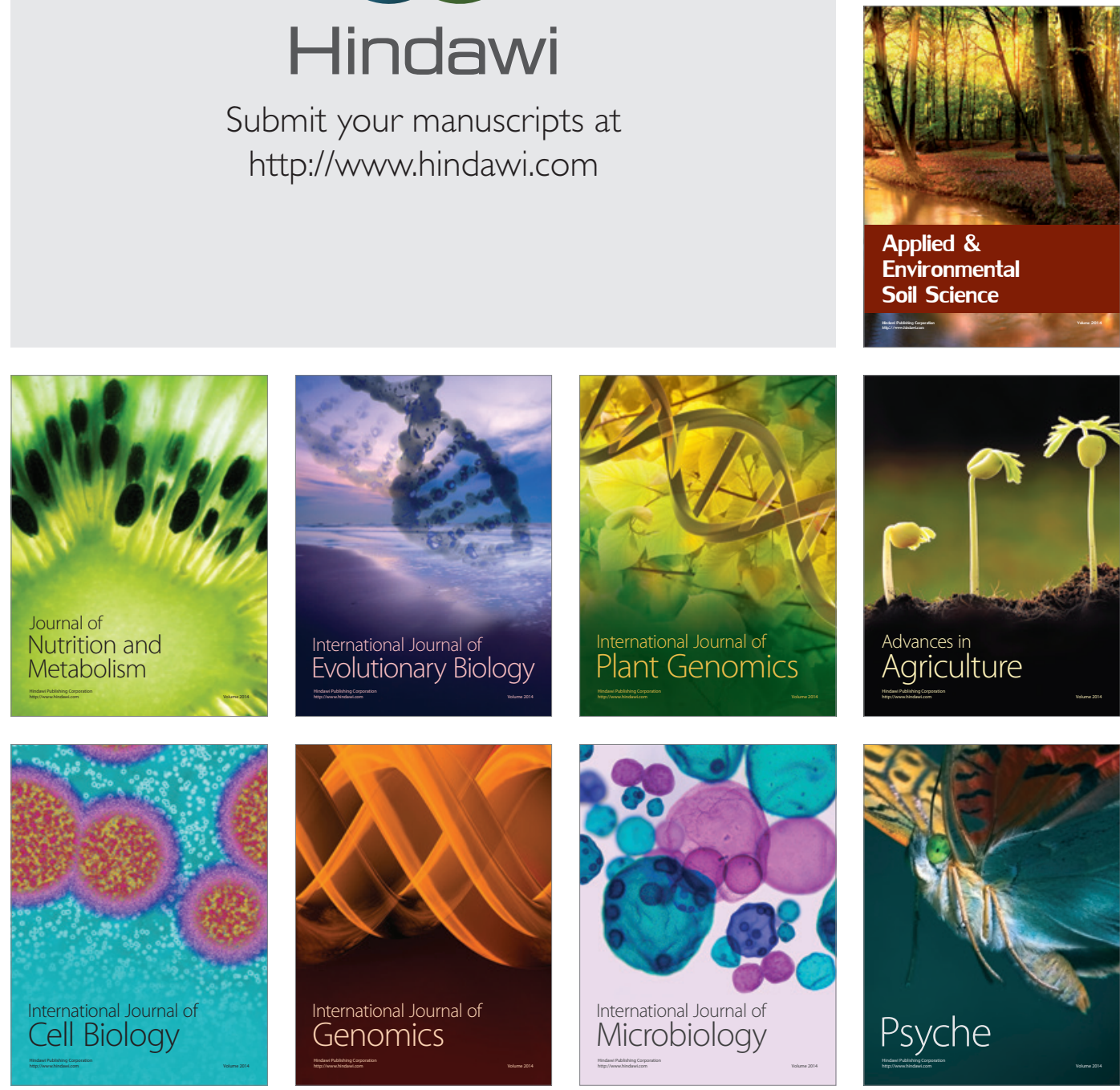
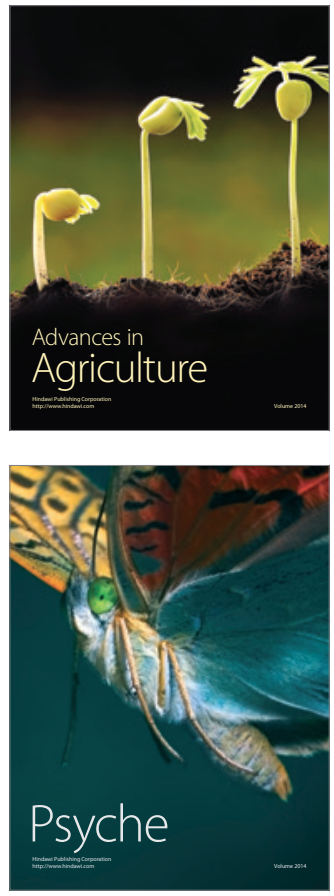